Revista Água Viva

ISSN 1678-7471

\title{
A NARRATIVA DE OS HABITANTES DE DALCÍDIO JURANDIR: UM OLHAR SOBRE O DIÁLOGO E A ORGANIZAÇÃO DAS VOZES ${ }^{1}$
}

\section{THE NARRATIVE OF OS HABITANTES BY DALCÍDIO JURANDIR: A LOOK AT DIALOGUE AND THE ORGANIZATION OF VOICES}

\author{
Flávia Roberta Menezes de Souza ${ }^{2}$
}

Recebido em: 12 out. 2018

Aceito em: 30 jan. 2019.

DOI 10.26512/aguaviva.v4i2.23843

RESUMO: O presente artigo apresenta a leitura da crítica sobre o romance Os Habitantes (1976) de Dalcídio Jurandir (1909-1979) no tempo de seu lançamento e relaciona essa primeira leitura a uma nova proposta de leitura do romance, embasada na teoria da narrativa de Gérard Genette e na teoria do romance polifônico de Mikhail Bakhtin.

Palavras-chave: Crítica Literária; Narratologia; Polifonia.

\begin{abstract}
This article presents a critical reading of the novel Os Habitantes (1976) by Dalcídio Jurandir (1909-1979) at the time of its release and relates this first reading to a proposed new reading of the novel, based on the theory of narrative Gerard Genette and the theory of the polyphonic novel by Mikhail Bakhtin.
\end{abstract}

Keywords: Literary Criticism; Narratology; Polyphony.

\section{Apresentação do romance no contexto da obra do autor}

O Dicionário de Teoria da Narrativa de Carlos Reis e Ana Cristina M. Lopes apresenta o termo história a partir de duas referências: Tzvetan Todorov afirma que a história "corresponderia à realidade evocada pelo texto narrativo (acontecimentos e personagens)"; e

\footnotetext{
${ }^{1} \mathrm{O}$ artigo é resultado da pesquisa Vozes e Tempos no romance Os Habitantes realizada como bolsista PIBIC/CNPq (2012-2013) no projeto O Inventário do Arquivo Dalcídio Jurandir (1909-1979) no Acervo-Museu da Literatura Brasileira (AMLB/FCRB) e nos Acervos Particulares do professor Dr. Gunter Karl Pressler.

${ }^{2}$ Professora EBTT do Instituto Federal de Educação Ciência e Tecnologia do Pará - IFPA. Graduada em Letras Habilitação em Língua Portuguesa pela Universidade Federal do Pará. Mestra em Letras pela Universidade Federal do Pará. Atualmente é doutoranda no Programa de Pós-graduação em Letras (PPGL) da Universidade Federal do Pará. E-mail: flaviaroberta1901@gmail.com
} 
Gérard Genette estabelece "história (ou diegese) como sucessão de acontecimentos reais ou fictícios que constituem o significado ou conteúdo narrativo" (REIS e LOPES, 1988, p. 49). A partir dessas definições, compreende-se a história ou diegese como acontecimentos inventados no contexto de uma narrativa ficcional. As referências à história real, no entendimento de Todorov, e como são comuns em interpretações da obra de Dalcídio Jurandir, não serão objeto de estudo deste trabalho.

Os Habitantes é o oitavo de dez romances que compõem a obra Extremo Norte de Dalcídio Jurandir. Nele, temos a continuação da trajetória do personagem Alfredo, que sai do Marajó aos doze anos, em busca de formação e estudo na cidade de Belém. Alfredo, desde o primeiro ano em Belém, vive como hóspede na casa de conhecidos da mãe. Em Os Habitantes, Alfredo tem aproximadamente dezessete anos de idade e vive um momento bastante conflituoso. Está cercado por um mistério cujo desfecho é incerto: o desaparecimento de Luciana. A narrativa desse conflito inicia-se no romance Primeira Manhã (1967), quando Alfredo ouve de D. Santa, personagem que o acolhe em Belém junto a D. Dudu, a história da sobrinha Luciana. A menina, assim como ele, morava no Marajó com a família. Era a caçula de três irmãos e era detestada pela mãe, D. Jovita. Esta não queria que a filha continuasse os estudos no ginásio, porém o pai, Coronel Braulino Boaventura, construiu uma casa em Belém para a caçula viver e estudar, mas a menina sequer chegou a morar na casa. Luciana foi violentamente castigada pela mãe, que disse ter visto a filha fazendo algo reprovável. Os dados a respeito dos motivos que levaram D. Jovita a espancar a filha não são precisos na narrativa, apenas sugeridos. A mãe a trancou nua no tabocal, onde ficavam guardados os selins dos cavalos. Sabendo disso, D. Santa foi buscar a sobrinha desabençoada pela família, para que vivesse sob os seus cuidados. Ao chegar a Belém, Luciana desaparece e nada mais é sabido sobre ela.

Dois acontecimentos muito importantes marcam a narrativa do romance: a chegada da família Boaventura em Belém e as decepções de Alfredo com seus estudos no Liceu. O espaço onde se desenvolve toda a história é a cidade de Belém e tem como personagens, além de Alfredo, os já conhecidos dos romances anteriores, coronel Braulino, D. Braziliana, D. Dudu, Ana, Dalila, Nini, D. Santa, D. Jovita, Graziela; e os novos Felipa, Floremundo, Zuzu. Na história há ainda personagens referenciais, ou seja, são apenas mencionadas e não movimentam o enredo: é o caso de D. Joinha, suposta amante de coronel Braulino; Jardelina, empregada na fazenda dos Boaventura; e Luciana, muito embora esta possua presença marcante no romance. 


\section{Dados contextuais do romance: o discurso da crítica literária de 1976}

Quando o romance Os Habitantes foi publicado, jornalistas e críticos como Raymundo de Souza Dantas, Fausto Cunha e Campomizzi Filho publicaram notas em periódicos anunciando a sua estreia. A maioria das referências encontra-se incompleta no que diz respeito à data de publicação e nome do periódico.

A coluna Livros no jornal $O$ Globo, de 27 de junho de 1976, escrita por Raymundo Dantas, noticiou a publicação de Os Habitantes com suas 160 páginas, pela editora Artenova e o valor em dinheiro na época: Cr\$30,00. O jornalista e escritor Dantas anunciou a continuação da obra de Dalcídio Jurandir, caracterizando-a como "minuciosa e pacientemente construída, com muita arte e igual dose de observação do social e do humano" e declarou ainda que o oitavo romance da saga Extremo Norte "restaura o fio autobiográfico do ciclo, desta vez, porém, temperado com o recordar e o exame das vivências de criaturas que já transitavam nos livros anteriores".

A percepção do crítico no que diz respeito ao trânsito de personagens de outros romances para este é legítima e característica importante não só de Os Habitantes como dos demais romances da saga, assim como o aspecto da memória. O fato é que, neste romance, o papel da memória tem um valor que vai muito além das representações de acontecimentos que marcaram a vida dos personagens. Como a análise do romance comprova, é por meio dos monólogos interiores e de lembranças, quase nunca por meio do discurso direto, da declaração, por assim dizer, "em voz alta", que o leitor conhece trechos fundamentais da história contada no romance.

Dantas atesta a qualidade do romance "embora de difícil leitura, pela sua construção e escrita". Essa constatação também foi compartilhada por Fausto Cunha em seu texto "Uma ficção que dispensa vitórias-régias", publicado na mesma data que o de Dantas. A diferença entre os dois críticos é que Fausto Cunha demonstrou uma compreensão diferenciada e maior sensibilidade quanto à técnica narrativa do romancista ao tentar formular uma visão acerca da construção do romance, pois como ele mesmo disse:

A aparente dificuldade do texto de Dalcídio e aquilo que Álvaro Lins chamou de monotonia derivam dessa preocupação de uma configuração verbal. $O$ romancista não firma compromisso com a aventura, com o enredo e sim com o homem e seu mundo, que seriam deformados por uma linguagem puramente narrativa (CUNHA, 1976, p. 23). 
Fausto Cunha critica os enquadramentos aos quais Dalcídio Jurandir ficou por muito tempo preso, ao do regionalismo e ao do romance social, mas afirma que não seria o rótulo de regionalista que afligiria o romancista, porque, segundo ele, a caracterização da cultura da região em sua obra foi mais importante que a fixação de aspectos da paisagem local. Logo, por conta dessa consciência demonstrada, "o romancista deve ter bem pouco de primitivo e bárbaro - ou de um narrador que escreva de impulso, como Jorge Amado ou José Lins do Rego" (CUNHA, 1976, p. 54).

O tom crítico ao se referir aos escritores da fase regionalista, Jorge Amado e José Lins do Rego, tinha a razão de dar ênfase a um aspecto singular percebido por Fausto Cunha na obra de Dalcídio Jurandir, pois “a recriação verbal presente em seus romances, uma visão do mundo que parte fundamentalmente da linguagem o distancia do regionalismo que virtualmente retrata o meio e é por ele retratado" (CUNHA, 1976, p. 67).

Ao final do texto, o crítico aproxima o romancista, já em sua fase mais madura, de Guimarães Rosa "não porque essa aproximação o valorize em detrimento de outras e sim porque em ambos há um lastro filosófico, uma visão própria da terra e do homem” (CUNHA, 1976. p. 68). A ideia que o crítico defende é a de que a obra de Dalcídio Jurandir precisa ser lida ou relida à luz de novos conceitos críticos. Ele reconhece certo hermetismo em Os Habitantes, mas graças a uma unidade estilística e elaboração de linguagem, "o leitor rapidamente se acostuma" (CUNHA, 1976, p. 78).

Campomizzi Filho, em um texto intitulado "Os Habitantes", construiu uma crítica de caráter aclamador acima de tudo, preocupando-se, inclusive, em destacar nomes de personagens do romance, levantando características particulares dos mesmos, como as de Floremundo e Felipa. Fez uma crítica mais centrada na história narrada pelo romance, abordando mais o aspecto temático, espacial e os sentimentos do autor perceptíveis por meio da construção do romance, sem tocar no aspecto formal, pois de acordo com ele "[Dalcídio] conhece como ninguém a paisagem amazônica. Ama aquele complexo de mata e de águas, uma gente sofrida e destemida enchendo aqueles claros e construindo ali uma civilização responsável pela continentalidade deste país" (CAMPOMIZZI, 1976, p. 53).

Percebendo um traço semelhante em Floremundo, personagem importante no romance, o crítico afirma que "Floremundo conhece a mata. Devassa-a dizendo os nomes de cada madeira e se referindo ao emprego de cada uma delas. Ama os pássaros e sabe de suas andanças. Admiralhes o voo. Acompanha-lhe o canto". Em outras palavras, a crítica de Campomizzi eleva Dalcídio ao posto de grande ficcionista brasileiro, que soma mais um título a sua quase dezena 
de romances e que já tem reconhecimento pelo seu "instrumental aperfeiçoado". Nesse ponto parece clara a ideia do crítico de que há na obra de Dalcídio Jurandir uma evolução, agora com o lançamento de seu mais novo romance.

\section{A Recepção acadêmica de Os Habitantes}

A primeira tese de doutorado sobre a obra completa do escritor foi escrita por Olinda Batista Assmar em 1992. Em 2003, o estudo foi publicado em livro com o título "Dalcídio Jurandir: um olhar sobre a Amazônia". Segundo a autora, Os Habitantes é "um romance citadino" e pertencente à "terceira fase de maturação do escritor", devido às transformações, evoluções e modificações narrativas, pois "nessa etapa, algumas características peculiares ao romance moderno são observadas, como o maior uso do monólogo, a diluição do enredo e a ambivalência caótica" (ASSMAR, 2003, p. 144). Nessa fase também se percebe na construção narrativa:

maior consciência e espírito crítico, razão por que elabora obras de grande reflexão social e psicológica quanto à vida da Amazônia, quer do citadino, quer daquele que vive às margens do baixo Amazonas ou do que permanece nos pequenos vilarejos de Marinatambalo (ASSMAR, 2003, p. 144-145).

Em 2010, foi publicado no livro Amazônia: região universal e teatro do mundo, organizado por Willi Bolle, Edna Castro e Marcel Vejmelka, um artigo de Gunter Karl Pressler, intitulado "O maior romancista da Amazônia - Dalcídio Jurandir - e o mundo do arquipélago de Marajó". Nesse trabalho o pesquisador não privilegiou aspectos de um ou de outro romance, mas falou da produção completa do romancista e acima de tudo ressaltou que "sua narrativa complexa e moderna estava muito além do horizonte de expectativa da crítica em meados do século XX, ainda presa a um determinado tipo de regionalismo do romance social" (PRESSLER, 2009, p. 238). O pesquisador compara Dalcídio Jurandir, "romancista de extensa obra envolvida por ideais de objetividade do estilo realista-naturalista" (PRESSLER, 2009, p. 235), a outros grandes escritores como Honoré de Balzac, Charles Dickens e Émile Zola. Compara também Dalcídio a Fiódor Dostoiévki pela sensibilidade do mundo subjetivo e psicológico, mais ainda a Marcel Proust pela complexidade narrativa de Em busca do tempo perdido.

Percebe-se, desse modo, que somente anos depois, na academia, Dalcídio Jurandir passou a ser reconhecido pela sua técnica de construção literária. Os métodos científicos no 
campo da teoria literária foram se modificando, junto à visão de "escritor menor" dada pelo contexto histórico em que publicou. Segundo Pressler:

A fundamentação simbólica (o leitmotiv) e a estrutura do ciclo exigem uma interpretação comparativa e uma análise da narrativa sob uma perspectiva moderna. Com o narrador ora na primeira, ora na terceira pessoa, com um discurso indireto livre e vários monólogos, estrategicamente entretecidos, a obra necessita de uma postura crítica mais capacitada. Os desdobramentos analíticos sobre a realidade e a percepção estética da realidade provocam uma personalização da narração, que ultrapassa as formas convencionais de narrar (PRESSLER, 2009, p. 246).

Há uma possibilidade de estabelecer um diálogo entre o posicionamento de Assmar e Pressler no que diz respeito ao reflexo do engajamento político na construção narrativa do romancista. Enquanto Assmar posiciona Os Habitantes na terceira fase da obra do escritor, por questões evolutivas de comprometimento e engajamento político, Pressler, sem considerar fases de maturação, afirmou que:

a postura politicamente engajada do romancista necessita de um complemento de discurso narrativo para não cair na trilha da literatura-panfleto ou do romance didático. James Joyce escreveu ao seu editor: 'My intention was to write a chapter of the moral history of my country' (BECK, 1985, p. 95), e não viu nenhuma contradição de fazer isso com uma técnica inovadora de narrar. Assim, pode se constatar, também no caso de Jurandir, uma postura moderna em relação à técnica narrativa (PRESSLER, 2009, p. 247).

Tanto Assmar quanto Pressler compreenderam, cada um a seu modo, a postura moderna de construção narrativa de Dalcídio Jurandir como um instrumento de inovação da técnica narrativa no romance, totalmente viável por uma ideia de fundo político, estrategicamente engajada:

Transfere o autor para o seu romance seus ideais políticos, aos quais aparentemente renunciara ao dar continuidade ao ofício de escrever. De fato, depois de atingir o ápice de seu projeto ideológico, recomeça sua atividade de escritor, retomando regionalismo amazônico, mais voltado para a alma do homem que para a sua vida material (ASSMAR, 2003, p.144).

A importância da narratologia no estudo de Os Habitantes torna-se então primordial para compreender o discurso moderno da narrativa empregado pelo romancista. É preciso tratar das peculiaridades da organização do discurso narrativo para esclarecer melhor o que os críticos 
de 1976 enxergaram como narrativa complexa e o que os estudiosos da literatura, mais tarde, compreenderam como postura inovadora e engajada frente ao discurso literário.

\section{Gérard Genette e o Discurso da Narrativa: a categoria voz.}

Das categorias apresentadas no estudo de Genette - tempo, modo, voz - essa última é a que subsidia o estudo acerca da narrativa de Os Habitantes. Tal escolha se deve ao fato de que para Genette essa categoria designa ao mesmo tempo as relações entre narração (ato de narrar em si, responsável pela existência do discurso narrativo) e narrativa (conjunto de conteúdos representados pelo discurso) e entre narração e história (enunciado narrativo), o que possibilita o presente estudo compreender as peculiaridades narrativas do romance de Dalcídio Jurandir.

Baseando-se no estudo de Genette, é possível destacar a relevância da narração no romance, visto que o enredo é repleto de "fendas" que abrigam outras narrativas no interior do mesmo. E essas outras narrativas existem porque os personagens sempre narram algum fato ou episódio no romance, ou seja, o ato de narrar é uma constante em Os Habitantes. Do mesmo modo, a narração contribui para a construção da história, do todo do enunciado narrativo. Sem narração não se conheceria o romance e sua história.

A categoria voz nos estudos de Genette se propõe a abordar a "instância produtiva" do discurso narrativo, já que é preciso compreender um enunciado levando em consideração quem o produz, ou seja, a narração que o produziu:

Como se sabe, a linguística levou algum tempo até abalançar-se a tratar aquilo a que Benveniste chamou a subjectividade da linguagem, ou seja, a passar da análise dos enunciados à das relações entre esses enunciados e a sua instância produtiva - o que se chama hoje a sua enunciação. Parece que a poética experimenta uma dificuldade parecida em abordar a instância produtiva do discurso narrativo, instância para que reservámos o termo, paralelo, de narração (GENETTE, 1995, p. 212).

Em Os Habitantes, há um narrador heterodiegético (narrador ausente da história que conta) responsável pela produção do discurso desde o início da narrativa do romance. Porém, em meio a um diálogo, uma narrativa é produzida por um personagem. A situação ocorre durante a longa conversa realizada entre Floremundo e Alfredo, na casa localizada na Rua José Pio em Belém. A instância narrativa deixa de ser o narrador e passa a ser Floremundo nesse momento: 
E com um olhar para o alpendre, ganhando uma cautela, chamou o Alfredo para o mais afastado:

- Vamos nos arretirando mais pra cá um pouquinho pois me deixe ir lhe dizendo. Foi na mesma noite do confete no piloto, assim pelas nove, o Utinga não sei se apitando, eu bem na beira do toldo em cima, ralando a onça de tabaco. Me virei: pelas proas, lado do necrotério, um zunzunzum. Firmei moa vista, era. Era que era então que só visto. Veio vindo. Um bando daquelas umas. Com voz de mascarados, ver piaçoca no lago. No geral vestidas a caráter. Tinha então uma, coberta numa plumagem, asa de anjo, escorria dela um luzimento, valia ver. Sustentava uma lança, mexia na asa, arpoava a lança e eu daqui só te olhando, só te olhando (JURANDIR, 1976, p. 34).

A instância narrativa no romance é predominantemente o narrador heterodiegético, mesmo a narrativa prosseguindo até o fim do romance mesclando o ato narrativo do narrador à fala dos personagens e seus monólogos interiores. Genette afirma ainda que:

uma situação narrativa [...] é um conjunto complexo no qual a análise, ou simplesmente a descrição, só pode distinguir retalhando-o um tecido de relações estreitas entre o acto narrativo, os seus protagonistas, as suas determinações espácio-temporais, a sua relação com as outras situações narrativas implicadas na mesma narrativa"(GENETTE, 1995, p.214).

Em outras palavras, a complexidade de uma situação narrativa só pode ser analisada se forem observadas a estreita relação entre o ato narrativo do discurso e os protagonistas da ação narrada; a maneira como se relacionam o ato narrativo e a situação espaço-temporal da narrativa contada; e, por último, como se relacionam o ato narrativo e as outras situações narrativas existentes na mesma narrativa. Partindo desse pressuposto, é possível definir o discurso narrativo em Os Habitantes do seguinte modo: a relação entre o ato narrativo e os protagonistas é caracterizada por uma forte proximidade, causada pela presença do discurso indireto livre, como é possível identificar no trecho em que a fala do narrador de repente se confunde com a de Alfredo:

Franziu a testa, franziu-se todo como se principiasse a descobrir que saltar aquela janela valia um destino, era um alcance, até onde não sabia. Que fazer desse destino, desse alcance, daquele salto? Que farei dele, dos instantes com a Esméia diante do espelho, debaixo do lustre, diante de tudo que ali lhes foi doado? (JURANDIR, 1976, p. 10).

A relação entre o ato narrativo e a situação espaciotemporal da narrativa de $O s$ Habitantes pode ser esclarecida pelo próprio fato de o narrador ser heterodiegético, ou seja, estar distante da situação narrada. O tempo, segundo Genette, é a determinação mais 
importante, pois é possível contar uma história sem precisar ao certo onde ela ocorre, pode-se não informar se o lugar onde a narrativa se passa está mais ou menos longe do lugar de quem a conta, mas não se pode deixar de situar a história no tempo em relação ao ato narrativo que a produz. $\mathrm{O}$ ato narrativo, simplesmente ao fazer uso de um verbo, já explicita uma relação temporal: presente, passado ou futuro. Desse modo, dentre as classificações de tempo da narração propostas por Genette - ulterior, anterior, simultânea e intercalada - a que se pode aplicar ao romance estudado é a ulterior, a posição clássica do ato narrativo: "Na narrativa clássica, essa distância é geralmente como que indeterminada, e a questão sem pertinência, marcando o pretérito uma espécie de passado sem idade" (GENETTE, 1995, p. 219).

Em Os Habitantes, por conta da presença de narrativas implicadas na mesma narrativa, observa-se a existência de níveis narrativos. No momento em que Alfredo conversa com Floremundo, os dois rememoram vários acontecimentos. Uma das recordações, narrada em pouco menos de três páginas, foi o carnaval vivido em Belém, como apresentado no destaque feito anteriormente. Nessa situação, observa-se não só a mudança da instância narrativa, como a mudança do nível narrativo, pois há uma narrativa dentro de outra. No mesmo diálogo, cuja instância narrativa é o narrador, mais narrativas surgem. É dessa forma que sabemos sobre Jardelina, que trabalhava na fazenda da família Boaventura e engravidou de Floremundo

Já o seu Floremundo olhava a cristaleira atulhada. Uma igual a essa, Jardelina algum dia viu? Nem-nem por sonho. Jardelina. Outra ocasião te levo na cidade, rapariga, disse a ela, uma tarde, por dizer Jardelina escutou, depenava a marreca. Jardelina ah pessoa sossegada. Seu Floremundo se amaciou por dentro, aquele sossego dela é minha melhor sustância [...] (JURANDIR, 1995, p.79).

Genette define então que "todo acontecimento contado por uma narrativa está num nível diegético imediatamente superior àquele em que se situa o acto narrativo produto dessa narrativa" (GENETTE, 1995, p. 227). Tal ideia aplica-se no discurso narrativo do romance, pois como pode ser ilustrado, a curta narrativa sobre Jaderlina, nunca mencionada em nenhum dos outros romances, teve origem a partir do pensamento de Floremundo. A história de Jaderlina está num nível diegético superior, pois é narrativa da narrativa e está, por assim dizer, duplamente inserida na diegese do romance. Pode-se definir que Floremundo e Alfredo fazem parte da narrativa diegética, enquanto que os acontecimentos contados a partir da memória de Floremundo, durante o diálogo com Alfredo, são "metadiegéticos” (GENETTE, 1995, p.227). Em outras palavras, há metanarrativas no discurso narrativo de Os Habitantes. Floremundo 
rememora muitos acontecimentos, além daqueles que motivaram sua vinda para Belém com a família. Ele lembra da irmã.

Seu Floremundo olhava agora a cozinha de porta aberta para o alpendre, as cabeças da família boiavam na claridade.

- Japu é como japiín [sic], os machos ficam cantando na exibição deles e as fêmeas nos ninhos trabalhando.

Explicação sem mais nem menos, para encobrir o que lhe grudava a língua, chegava se escurecer por dentro. Meu filho, de tudo isto chega. Só moela de mutum mói tudo isto.

Neste grude, nesta escurecença quando vejo, é ela.

Com ela na garupa, ou no banco da montaria, caçando marreca debaixo do mururezal, metia-se. Deus o livre, ali sustendo o fôlego, vigiando as aves. Aquele bando delas descendo na baixa que se avermelhava. Então, inocentes do caçador e da vigia, começavam a comedia delas. Por baixo do boi marrequeiro, com a espingarda que carrega pela boca, boi nem se mexendo o pau falou, o estouro, a nuvem, o marrecal subindo, e saltando da água a Luciana com a embiara, era ver filma no fundo, com aquele dizer só dela toqueestoloque toqueestoloque.

Vendo o irmão sair para o campo (um cerco de jacaré ou pirarucu num braço), a oferecida:

- Ah até que sonhei, esta noite, que o meu bom do mano ia me levando com ele, agora. Dito e certo, vou? Toqueestoloque. Me levando? (JURANDIR, 1976, p. 49)

Certamente, essas características da narrativa do romance foram responsáveis pela sua qualificação como hermético pela crítica de 1976. Grande parte dos conteúdos metadiegéticos se encontra inserida nos diálogos. Entretanto, na relação entre as vozes nos diálogos há mais situações que necessitam de estudo, mas que fogem ao domínio da narratologia proposta por Gérard Genette. Se por um lado ao dialogarem os personagens produzem narrativas e fazem do ato narrativo uma atividade significativa para a construção do romance, por outro, as vozes responsáveis pelos diálogos são produtoras de um discurso, em que um discurso está para o outro.

\section{Os diálogos em Os Habitantes}

No trabalho Problemas da Poética de Dostoiévski, Mikhail Bakhtin apresenta sua tese do romance polifônico. Segundo o filósofo, Dostoiévski é o criador do romance polifônico, gênero em que a voz da personagem "possui independência excepcional na estrutura da obra, é como se soasse ao lado da palavra do autor, coadunando-se de modo especial com ela e com as vozes plenivalentes de outros heróis" (BAKHTIN, 2010, p. 5). O conceito de polifonia é 
elaborado ao longo de toda obra, de modo que Bakhtin ratifica a superioridade dialógica do romance polifônico, "conferindo a este um teor mais realista" (COMPAGNON, 2010, p. 109), ou seja, mais aproximado da concepção de linguagem defendida pelo filósofo. Se o romance é um gênero dialógico por excelência, o romance polifônico apresenta o caráter dialógico de modo mais acentuado ainda, conseguindo captar e engendrar a multiplicidade de vozes existente no discurso romanesco de modo visível e transparente.

Emprega-se o termo polifonia para caracterizar um certo tipo de texto, aquele em que se deixam entrever muitas vozes, por oposição aos textos monofônicos, que escondem os diálogos que os constituem. Reserva-se o termo dialogismo para o princípio constitutivo da linguagem e de todo discurso (BARROS, 2003, p. 5-6).

No romance Os Habitantes, a presença de gêneros retóricos é intensa. Destaca-se o gênero oral conversa informal, apresentado por meio de um longo diálogo que se inicia na página 32 e continua até a página 117. O diálogo entre Alfredo e Floremundo é muito significativo na história do romance. Ele apresenta-se como um dos momentos em que os personagens revelam suas maiores angústias, dúvidas e sofrimentos por meio da linguagem. Durante o diálogo, o leitor sabe o que os personagens enxergam a seu próprio respeito e a imagem que constroem do seu próximo, do outro.

Apesar de o diálogo ser o tipo que melhor oportuniza a aparição das vozes, não é simplesmente a sua presença que faz do romance um gênero polifônico. Para isso é importante deixar claro que, na perspectiva bakhtiniana, as vozes seriam "consciências valorativas que reagem a, isto é, que compreendem ativamente os enunciados" (ZOPPI-FONTANA, 2011, p. 111). Se as vozes no romance não se comportam como consciências autônomas, plenas de uma ideia particular sobre si mesmas, sobre o mundo e sobre o outro, elas deixam de representar a linguagem em seu sentido vivo, tornando-se meramente objetos ou veículos da ideia de uma instância superior. Essa voz como objeto veicularia simplesmente as ideias do autor, consciência formadora, capaz de conferir acabamento aos personagens. Estar-se-ia diante de um romance não mais polifônico, porém monológico.

Do mesmo modo, é preciso afirmar que não se identifica polifonia apenas em diálogos. No romance estudado é muito clara a presença das vozes em constante atividade de leitura própria do mundo, inseridas em monólogos interiores. Enquanto Floremundo conversa com Alfredo, os dois se perdem em divagações: o primeiro lembra-se da irmã, o segundo da mãe. A reunião na sala entre o coronel Braulino, Jovita e as duas irmãs, também não deixa de estar 
presente na mente de Floremundo, mesmo falando com Alfredo, simultaneamente, sobre um assunto totalmente diferente. Excluído da reunião pelas mulheres da família, Floremundo chega a formular em sua cabeça a ideia de que o paradeiro da irmã pode ser desvendado pelo mistério das cartas, supostamente de uma amante, encontradas pela mãe nas fronhas dos travesseiros do pai:

Seu Floremundo saltou de suas cismas:

- Era um mutum açu, o que levei pra casa de sua mãe.

Casa de seu pai, quis emendar, não emendou, satisfeito.

Lá da mesa pareceu sair um regougo. Os dois aqui se caiavam. Seu Floremundo pensou: o caminho, quem sabe, que o velho via, ou dela se aproveitou, ou aproveitado pela amante, para tirar da toca a perdida.

- Seu Floremundo, não me lembro bem. Bem bem, não.

- Ah mas já faz bote que tempo. Peso de tempo. Dei também um pro seu Saiu, esse um mutum pinina, com topete senhor topete. Um penacho que o mutum tem, serve pra encastoar em ouro.

No balaio da caçula, agora da Graziela, aqueles tantos encastoados, o trancelim, a corrente...

- É preto-preto. Lustroso do lustroso.

Meu Deus, da mesma tinta e lustro o cabelo da caçula. Olha, mano, cor deste meu cabelo e cor do penacho do mutum tirado é da mesminha tinta. [...]

Também Alfredo via nos tios, um pouco na mãe, a cor do penacho do mutum, lustroso de rosto e sossego no banho, beirada e ladainha, no baile de Santana, no leme do barco, no lombo do cavalo. Mutum e tios, da mesma família. (JURANDIR, 1976, p. 42).

Outra característica importante diálogos é a presença da voz de Luciana. As constantes aparições dessa voz são uma característica forte e particular desse romance, pois se trata de uma personagem que, em caráter físico nunca está presente. Por outro lado, a presença da sua voz, tomando como princípio a ideia de voz estabelecida por Bakhtin, é tão forte e facilmente delineada no discurso do romance, que a mesma passa a se relacionar dialogicamente com a voz do irmão, o responsável pelas nítidas lembranças de Luciana.

Aqui seu Floremundo vergou-se um pouco mais, estalou os dedos, coçou-se nas costas, olhou as alturas da noite.

- Deixa ar que eu crio, disse ela. Um dia, o macho derrama da cuia a garapa que a mea irmã fazia da batata da aninga. Ela costumava levar a batata da aninga no quente das cinzas, depois lavava, ia espremendo, ia espremendo, até que desse um caldo igualzinho garapa de cana, só que sem a doçura. Com isto Luciana...

Escapou como um gemido. Há quanto sem soltar o nome. Podia? Varrido não foi tudo em casa o que lembrava a caçula? Vem o rapaz, esse — as coisas! me tirando o nome da boca, me espreme um pouco aqui por dentro. Pouco é mas tira o tamanho. (JURANDIR, 1976, p. 43). 
A relação dialógica que ocorre entre as vozes de Floremundo e Luciana não diz respeito ao emparelhamento de pontos de vista divergentes ou conflituosos. Na verdade, a própria presença da voz da irmã no interior da consciência de Floremundo desperta sentimentos como remorso, arrependimento, dor, amargura que se contrapõem ao aparente estado de que está tudo bem na ausência da menina, ou de que o seu desaparecimento não afetou aquela família. A presença da voz da menina se contrapõe à sua ausência física, permitida pela família sem nenhuma contestação de Floremundo. Mesmo na sua ausência física, a presença de Luciana é responsável pela existência de uma voz no romance que contrasta e "briga" com a voz e a presença física da família.

A loção de Graziela não protegia as senhoras nem a casa. A família trazia os odores da condenada. Neste jenipapo que se abre, naquele couro de maracajá, no beiju grosso, é o chão, o igarapé, os cavalos, a grossa tarde de urro e fogo, a ferra no curral, a moça em cima da tranca anotando as reses ferradas. Luciana brandia a marca do ferro em brasa, marcava a testa de cada um da família. (JURANDIR, 1976, p. 15).

No capítulo destinado a discussão das Peculiaridades do gênero, do enredo e da composição das obras de Dostoiévski, Bakhtin fornece grande contribuição para o entendimento das relações dialógicas no monólogo interior em Os Habitantes. Ele afirma que “o enfoque dialógico de si mesmo rasga as roupagens externas da imagem de si mesmo, que existem para outras pessoas, determinam a avaliação externa do homem (aos olhos dos outros) e turvam a nitidez da consciência-de-si”" (BAKHTIN, 2010, p. 137). E um dos momentos mais significativos da história ocorre durante as reflexões de Alfredo, que vive um conflito filosófico humano. Não sabe que caminho tomar na vida para alcançar a plenitude, que desde a infância sonhara. O rapaz sempre achou que essa plenitude pudesse ser alcançada nos estudos em uma instituição de ensino propriamente dita, mas aos poucos vai descobrindo que esse pode não ser o seu caminho. Que o ginásio não é, talvez, o caminho que irá leva-lo aonde gostaria de chegar.

Por outro lado, Alfredo precisa lidar com a admiração que a sua figura de ginasiano e estudante de francês desperta na mãe, nas vizinhas da rua e etc. Floremundo vê em Alfredo um homem e resolve lhe confidenciar um segredo e essa "roupagem externa" que Floremundo lhe confere assusta o rapaz:

— Olhe, seu Alfredo, o favor que lhe pedi, só no meio da viagem, lhe vou explicando qual. Mas menino o senhor já não é, que eu sei, taludo que ficou, tamanho! Confio no homem que já vejo no senhor, que eu sei. Então me espere, paciência, é o tico de tempo em que mudo esta camisa, é só mudar. 
Alfredo, pela varanda e por dentro de si mesmo, deu de novo com o cachimbo, o sarro e a ferocidade da D. Jovita.

Que homem é que vê em mim? Indagação quase assustada, um ter de descobrir quem sou, que não ia longe. Comparou o seu Floremundo aos professores do Ginásio, Esse-um fedendo a boi, sangrando com a ausência da irmã, dele vem uma voz. É dos professores?

O convite do seu Floremundo era correr Belém até encontrar aquela a quem os dois, por todos, devem pedir perdão?

$\mathrm{Ou}$ sou eu que estou, pela primeira vez, encontrando um homem? (JURANDIR, 1976, p. 80-1).

Alfredo lida, de fato, com várias "roupagens externas" que lhe são impostas ao longo do romance. $\mathrm{O}$ rapaz suspeita que Floremundo enxerga nele, a irmã no ginásio:

— Suas lições, hoje? Quero crer que o sono lhe tirou a visão do estudo. Ou não?

Alfredo parou o garfo: esse homem está falando comigo ou com a irmã que chega do Ginásio? No olhar dele, estou eu ou ela? (JUARANDIR, 1976, p.75).

Nini enxerga em Alfredo um menino talentoso para os estudos, inteligente: "Meu tio Floremundo em breve esse aí, esse moreninho, está com um canudo na mão atado com uma fita cor de rosa" (JURANDIR, 1976, p. 19). O mesmo pensa a mãe de Zuzu, ao pedir que Alfredo dê aulas para o filho caçula dela:

Pois olhe, seu Alfredo, quandozinho puder ter um tempo mas só quando o senhor tiver, que eu sei que o seu estudo ocupa é horas. Olhe, vá pondo de parte umas tantas coisas. Mãe, por via de filho, não mede. Agora que sei que o senhor é pobre nem esconde que é, já me sinto mais... o senhor me tirou do apuro. (JURANDIR, 1976, p. 72).

Mas ouve a seu respeito o oposto do secretário do ginásio:

O senhor falta ao tiro, falta ao desenho, falta à concentração cívica. Desacatou, ano passado, o lente de latim. Acusado de colar um rabo no professor de matemática. Entrou, quando não era, na aula de química. Errou a porta, rapaz, errou a porta. Monte banca de bicho. Trabalhe de catraieiro. Tão tamanho bigú! (JURANDIR, 1976, p. 63).

Mais adiante, Alfredo questiona-se "Correu até a porta da rua, espiou o campo, o canto, a jaqueira, a Penitenciária. Voltou: que é que faço do Ginásio? Ou o que é que o Ginásio faz de mim?" (JURANDIR, 1976, p. 82).

No romance de Dalcídio Jurandir é possível conhecer e compreender os personagens 
porque eles próprios se revelam pela sua linguagem, os diálogos e os monólogos interiores apenas lançam o foco para eles, dando a oportunidade para que os mesmos se definam enquanto sujeitos cheios de dúvidas, incerteza, angústias e etc. Como Bakhtin afirma sobre Dostoiévski, "A autoconsciência do herói em Dostoiévski é totalmente dialogada: em todos os seus momentos está voltada para fora, dirige-se intensamente a si, a um outro, a um terceiro" (BAKHTIN, 2010, p. 292). Floremundo é exemplo dessa autoconsciência, pois, ao ser interrogado por Alfredo sobre o dia fatídico em que quase a irmã morre, sentiu o impacto da pergunta, o que lhe gerou o silêncio e a mudança de assunto com a finalidade de evitar sofrimento. O nome de Luciana, a lembrança do destino da irmã causa dor no homem:

- No dia daquele raio, o senhor estava?

— Não. Caçava.

- Que raio, não?

- Sim, senhor, foi. Cheguei depois. A faísca partiu o bacurizeiro em duzentos e cinquenta e dois pedaços pequenos e dezesseis pedaços grandes que dois homens não suspendiam.

- E antes?

- Que antes?

- Sim, antes do raio.

Seu Floremundo desatou a gravata, tirou o colarinho, embolou tudo no bolso da calça, pendurou o paletó no braço, deu um trago forte, deu um passo até ao limoeiro, Alfredo sentiu que tinha se adiantado.

Seu Floremundo olhava agora a cozinha de porta aberta para o alpendre, as cabeças da família boiavam na claridade.

- Japu é como japiín, os machos ficam cantando na exibição deles e as fêmeas nos ninhos trabalhando.

Explicação sem mais nem menos, para encobrir o que lhe grudava a língua, chegava se escurecer por dentro. (JURANDIR, 1976, p. 49).

Bakhtin, utilizando Dostoiévski como exemplo, formula:

representar o homem interior como o entendia Dostoiévski só é possível representando a comunicação dele com um outro. Somente na comunicação, na interação do homem com o homem revela-se o 'homem no homem' para outros ou para si mesmo (BAKHTIN, 2010, p. 292).

Essa ideia de revelação do homem no homem por meio da linguagem confere ao romance polifônico um caráter realista na medida em que as profundidades da alma humana são reveladas e apresentadas no momento do diálogo. Esse aspecto do realismo tão defendido por Dostoiévski em seus romances é identificado no romance de Dalcídio Jurandir. 


\section{Vozes sobre Luciana}

Luciana possui uma presença especial na história do romance. Ao mesmo tempo em que a fala da menina é expressa por meio do discurso direto, a mesma encontra na fala e na memória do irmão espaço para se expressar. De outra forma, jamais seria possível o leitor ter acesso à voz de Luciana, pois sua presença física inexiste.

- Também se criou um japu. Ela criou com gema do ovo. O japu pintava! Furtava os óculos do papai, o cachimbo da mea mãe, as pulseiras da Graziela, tudo levando no bico. Ninho dele é como um balde, no bojo põe o ovo, a boca do ninho que nem boca de cachimbo, nunca chove dentro. Bicho que era bicho que tinha em casa! A caçula era muito xerimbabeira. Os bichos naquele pegadio com ela. Chegou de amansar, a bem dizer debaixo do sovaco, um acuatipuru encarnado, que estoriam que encanta folha de qualquer mato, virando a folha em pé de milho, em banana.

Faz um milharal daquele mirizeiro, e já espigando, anda! ordenava a caçula. Quero agora mesmo desta sororoca um cacho de banana inajá, anda! (JURANDIR, 1976, p. 44-5).

As falas de Luciana tornam o dialogismo presente no discurso do romance um arranjo de vozes visíveis e a sua imagem é sempre construída valendo-se da palavra do irmão, que a descreve, e, a essa descrição soma-se a voz da própria Luciana. Tudo o que se conhece de Luciana, enquanto sujeito no mundo, o é por meio do discurso de Floremundo.

Em efeito, segundo Bakhtin, a minha aparência é sempre construída a partir da representação que o outro produz de mim: a autoconsciência do meu ser no mundo só se dá através da compreensão ativa e valorativa do outro que me enxerga enquanto corpo exterior que se destaca do seu entorno. (ZOPPIFONTANA, 2011, p. 111).

Na segunda parte do romance, é Graziela quem ganha enfoque no discurso. Mais uma vez é possível observar um olhar sobre Luciana: o discurso de Graziela aciona a voz revoltosa de Luciana no discurso narrativo contra Graziela. Graziela reconhece, em meio a um monólogo interior, os talentos da caçula e a inveja que isso lhe causava.

Lá no Jandiá a ofensa de bubuia, a água bem dormindo, amanheceu de bubuia, pendurou-se no arco-íris é um dos pedaços do taperebazeiro, abre um dos porcos mortos é a ofensa saindo da tripa, o pica-pau pregando o eco, e arriscou ver no quarto, no selim, os salpicos do sangue, o feitio daquele corpo suado, chicoteado, fêmea que só ela, que quanto mais a mãe batia mais o corpo se 
ostentava, rosto, peito, barriga, bunda, o feitio bem gerado - que é só meu, que tu igual não tens, cachorra. Era o que vinha do selim, a danada já sem pele, cada uma roxidão escurecendo as costas, a pisa do relho da mãe. Mas debaixo da surra saltava a mesma menina, aquela, de repente sabendo ler, escrever e contar, respondia tudo na bucha, desembaraço que só visto oh, memória! Num instante fez colegas, mestra, gente grande, vissem nela a de mais cabeça. $\mathrm{O}$ escurão que me deu por dentro, com a unha arranhando a parede, a ouvir os gabas e ter de dizer: sou irmã dela. (JURANDIR, 1976, p. 119).

Segundo Jardelina, a moça que engravidou de Floremundo e trabalhava na fazenda, Graziela teria feito um chá para a irmã, cujo efeito teria provocado a perda do juízo de Luciana. Possivelmente, Luciana teria desaparecido por conta de alguma maldade feita pela inveja da irmã: "Vigie só. Já inteirou mês que também escutei que a mea comadre, a sua irmã caçula, bebeu inocente num chá a raspa de unha ralada. Consiga o rastro de sua irmã, seu Floremundo" (JURANDIR, 1976, p. 60). A possível maldade feita contra Luciana explicaria a voz da menina acusando Graziela: “Cachorra!”. A voz de Luciana ecoa em resposta ao que the foi feito.

Dessa maneira, é possível constatar o intenso plurilinguismo em Os Habitantes, provocado por essa voz que não tem presença física. A fala de Luciana ora se expressa com um tom carinhoso de uma irmã para o irmão, ora com um tom revoltado contra a inveja da irmã. Essas formas diversas de expressão de uma voz se apresentam sempre em situação de diálogo. É sempre por meio do diálogo com outra voz que Luciana fala e se expressa. Sua voz é carregada de uma postura reversiva em relação ao que se poderia esperar de uma menina com suas origens e criação. Prova dessa questão é a surpresa com que Alfredo chega ao Ginásio, no seu primeiro dia de aula, e percebe que só ele, com todo o esforço da mãe, conseguiu alcançar o sonho dos estudos. Quantos meninos e meninas poderiam estar no mesmo caminho que ele, mas por uma diversidade de motivos, não estão.

Outro ponto interessante é a postura das irmãs de Luciana. Felipa sempre foi passiva, aparentemente, não tinha sonhos. Era sempre muito quieta. Já Graziela, sempre sonsa, nunca aprendeu a tocar seu bandolim. Era frustrada e não suportava ver a irmã caçula, sempre cheia de atitude, querer saber mais, a ponto de desejar morar em Belém para frequentar o Ginásio. A mãe, D. Jovita, era analfabeta. Graziela era a responsável por fazer leituras de documentos na casa, era a autoridade, a "principala", como diziam os irmãos. Luciana era o oposto de tudo aquilo, de todas as mulheres de sua família, era a representante de uma voz sempre em conflito com a voz das mulheres de sua família.

Esse conflito travado na própria linguagem e representado por ela foi o que Boris Schnaiderman destacou como o maior interesse de Bakhtin, pois é nesse conflito que se pode 
enxergar a manifestação das diferentes vozes (SCHNAIDERMAN, 2011, p. 17). O mesmo conflito faz de Os Habitantes um romance em que a linguagem ganhou, sem sombra de dúvidas, o destaque tanto priorizado por seu autor e criador, Dalcídio Jurandir.

\section{REFERÊNCIAS}

ASSMAR, Olinda Batista. Dalcídio Jurandir: um olhar sobre a Amazônia. Rio de Janeiro: Galo Branco, 2003.

BAKHTIN, M. M. Problemas da poética de Dostoiévski. Tradução direta do russo, notas e prefácios de Paulo Bezerra.

Bezerra. 5 ed. rev. Rio de Janeiro: Forense Universitária, 2010.

BARROS, Diana Luz Pessoa de. Dialogismo, Polifonia e Enunciação. In: FIORIN, José Luiz (Orgs.). Dialogismo, polifonia, intertextualidade: em torno de Bakhtin. São Paulo.

COMPAGNON, Antoine. O demônio da teoria: literatura e senso comum. Tradução de Cleonice Paes Barreto Mourão, Consuelo Fortes Santiago. 2 ed. Belo Horizonte: Editora UFMG, 2010.

CUNHA, Fausto. Uma ficção que dispensa vitórias-régias. [S.1], 27 jun. 1976.

DANTAS, Raymundo Souza. O romancista concentra os seus recursos. O Globo, São Paulo, 27 jun. 1976.

FILHO, Campomizzi. Os Habitantes. [jornal não identificado, S.1.], 1976.

FURTADO, Marli Tereza. Universo derruído e corrosão do herói em Dalcídio Jurandir. Campinas, SP: Mercado de Letras, 2010. (Coleção histórias de leitura).

GENETTE, Gérard. O discurso da narrativa. 3 ed. Lisboa: Veja, 1995.

JURANDIR, Dalcídio. Os Habitantes. Rio de Janeiro: Artenova, 1976.

JURANDIR, Dalcídio. Primeira manhã. 2 ed. Belém: Eduepa, 2009.

JURANDIR, Dalcídio. Ponte do Galo. São Paulo: Martins, 1971.

PRESSLER, Gunter Karl. O maior romancista da Amazônia - Dalcídio Jurandir - e o mundo do arquipélago do Marajó. In: BOLLE, Willi; CASTRO, Edna; VEJMELKA, Marcel (org.). Amazônia: Região Universal e Teatro do Mundo. Globo: São Paulo, 2010.

REIS, Carlos; LOPES, Ana Cristina M. Dicionário de Teoria da Narrativa. São Paulo: Ática, 1988. 
Revista Água Viva

ZOPPI-FONTANA, M. G. O outro personagem: enunciação, exterioridade e discurso. In: BRAIT, Beth (Org.). Bakhtin, dialogismo e construção do sentido. $2^{a}$ ed. rev. Campinas, SP: Editora da Unicamp, 2011. 